\title{
Pelatihan Parenting Pendampingan Anak Belajar Di Era Digital
}

\section{Tesaviani Kusumastiwi1}

Program Studi Pendidikan Dokter, Fakultas Kedokteran dan Ilmu Kesehatan, Universitas Muhammadiyah Yogyakarta Jl. Brawijaya, Geblagan, Tamantirto, Kec. Kasihan, Yogyakarta, Daerah Istimewa Yogyakarta 55183

Email : tesaviani.kusumastiwi@gmail.com

DOI: $10.18196 / p p m \cdot 34 \cdot 281$

\begin{abstract}
Abstrak
Anak yang terlahir di era digital memiliki karakter mudah menyerap perkembangan teknologi dan mengutamakan kenyamanan. Hal ini menjadikan media digital sebagai kebutuhan anak, termasuk kebutuhan dalam belajar. Media digital tidak hanya memberikan dampak positif, namun juga dampak negatif. Peran orangtua sangat diperlukan dalam mendampingi penggunaan media digital, akan tetapi tidak semua orangtua memahami karakter anak di era digital dan aturan dalam penggunaan media digital. Pelatihan ini ditujukan untuk meningkatkan pemahaman orangtua mengenai pendampingan belajar di era digital. Pelatihan dilakukan dengan metode daring yang terdiri dari dua sesi. Pretest dan postes dilakukan sebagai sarana evaluasi pelatihan. Didapatkan perbedaan skor pengetahuan yang bermakna secara statistik sebelum dan sesudah pelatihan dilaksanakan. Feedback positif didapatkan dari peserta setelah mengikuti pelatihan baik secara materi, penyampaian maupun kemanfaatan dan ketepatan materi pelatihan dengan kebutuhan mitra pengabdian. Pelatihan ini dapat secara efektif meningkatkan pengetahuan orangtua mengenai pendampingan belajar anak di era digital.
\end{abstract}

Kata Kunci: digital, gawai, gaya belajar, parenting

\section{Pendahuluan}

Perkembangan teknologi menjadikan media digital tidak dapat dipisahkan dalam kehidupan sehari-hari. Survei menunjukkan penetrasi media digital mencapai 54,68\% dari total populasi di Indonesia (APJII, 2017). Perkembangan dunia digital ini menjadikan munculnya generasi digitival native, yakni generasi yang sedari lahir telah terpapar dengan teknologi tinggi (Paudel, 2017). Generasi ini memiliki sudut pandang dan karakter yang berbeda (Kildare, 2017). Salah satu tugas perkembangan digital native adalah belajar. Media digital merupakan salah satu sarana yang dapat menunjang proses belajar. Peran orangtua sangat penting dalam mendampingi penggunaan media digital untuk belajar (Wonsun, 2018), namun tidak semua orangtua memahami karakter digital native dan aturan dalam penggunaan media digital.

Penelitian Steel (2015) menunjukkan adanya berbagai dampak negatif dalam penggunaan media digital, antara lain agresivitas, pornografi maupun adiksi. Salah satu kelompok yang rentan adalah anak usia 6-12 tahun. Menurut teori perkembangan Jean Piaget, pada usia 6-12 tahun anak masih memerlukan pengawasan dari orangtua mengingat kemampuan kognitif usia tersebut berada pada tahap operational abstract (Saddock, 2010). Arti dari tahap ini adalah seorang anak belum memiliki abstraksi untuk menimbang risiko ke depan yang akan dihadapi. Hal ini menjadikan peran orangtua cukup vital dalam menjaga anak dari perilaku menyimpang. Selain sebagai pengawas dalam penggunaan media digital untuk belajar, pemahaman orangtua mengenai gaya belajar anak juga merupakan faktor penting untuk mendukung kemudahan dan kesuksesan anak dalam belajar (Huntsinger, 2009).

SD Muhammadiyah Karang Tengah, merupakan SD yang terletak di kawasan suburban dengan kemajuan infrastruktur yang pesat, salah satunya adalah kemudahan akses dunia digital. Berdasarkan informasi dari perwakilan orangtua siswa, hampir dalam setiap pertemuan orangtua murid, permasalahan terkait dengan media digital senantiasa muncul, antara lain: perilaku kekerasan anak yang mengakses game ke gangguan emosional saat dijauhkan dari gawai dan banyaknya waktu yang dihabiskan anak untuk mengakses media digital. Di sisi lain, saat ini 
penggunaan media digital merupakan sarana yang sangat penting dalam mendukung proses belajar. Pelatihan ini ditujukan untuk memberikan pengetahuan kepada orangtua siswa mengenai karakter anak digital native, aturan penggunaan media digital dan indentifikasi gaya belajar anak.

\section{Metode Pelaksanaan}

Tahap persiapan pengabdian berisi kegiatan perijinan dan koordinasi persiapan pelaksanaan dengan mitra pengabdian yakni Paguyuban Orang Tua Siswa. Pelatihan dengan metode daring disepakati dengan pihak mitra pengabdian, sebagai adaptasi terhadap kondisi pandemi. Rekruitmen peserta dilakukan pihak mitra berkoordinasi dengan pihak sekolah, dengan memilih beberapa orangtua siswa yang memiliki kendala dalam mendampingi anak belajar. Pihak sekolah mengumpulkan sekitar 46 peserta. Pelatihan dilaksanakan dalam dua sesi, sesi pertama berisi pemaparan virtual mengenai pengetahuan karakter anak dan aturan dalam penggunaan media digital. Sesi kedua berisi pemahaman mengenai gaya belajar anak dan adaptasi penggunaan media digital untuk mendukung proses belajar sesuai dengan gaya belajar anak. Sesi kedua didahului dengan pengisian kuesioner skrining gaya belajar anak sehingga saat pemaparan materi, setiap orangtua sudah mengetahui gaya belajar anak masing-masing. Pretest dan postest disiapkan dalam bentuk google form digunakan sebagai evaluasi pemahaman pemaparan materi. Feedback peserta digunakan sebagai refleksi terhadap pelaksanaan pelatihan. Tanya jawab interaktif dilakukan baik secara video maupun chat pada waktu yang disediakan. Analisis data dilakukan menggunakan hasil pengisian kueisoner yang berisi karakteristik peserta dan nilai pretest-posttest. Dilakukan analisis statistik pada perbedaan rata-rata skor pretest dan posttest untuk diketahui kemaknaannya secara statistik.

\section{Hasil dan Pembahasan}

Pelatihan dilaksanakan dalam 2 sesi. Sesi pertama diawali dengan pretest dan skrining gaya belajar anak yang disajikan dalam bentuk google form. Pemaparan sesi pertama berisi pengetahuan mengenai karakter anak digital native, dampak negatif penggunaan media digital dan aturan dalam penggunaan media digital oleh anak. Beberapa tips komunikasi dalam menghadapi kendala terkait penggunaan media digital disampaikan dalam sesi tersebut. Tanya jawab interaktif dilaksanakan di akhir sesi pertama.

Sesi kedua diawali dengan penjelasan hasil kuesioner gaya belajar anak, sehingga orangtua telah dapat mengidentifikasi gaya belajar masing-masing anak. Sesi kedua dilanjutkan dengan pemaparan materi mengenai proses belajar, gaya belajar dan tips adaptasi pendampingan belajar sesuai dengan gaya belajar anak. Penutupan dilakukan setelah sesi tanya jawab materi kedua dengan memberikan google form berisi posttest dan feedback dari peserta pelatihan. Adapun karakteristik peserta pelatihan disajikan pada tabel 1.

Tabel 1. Karakterisktik Peserta Pelatihan

\begin{tabular}{llrr}
\hline Variabel & Keterangan & Prosentase & Mean \\
\hline Jenis Kelamin Peserta & Laki-laki & $0 \%$ & \\
Usia Peserta & Perempuan & $100 \%$ & 37,03 \\
Usia Anak & & & 8.54 \\
Jenis Kelamin anak & Laki-laki & $47.8 \%$ & \\
& Perempuan & $52,2 \%$ & 62.39 \\
Rata-rata nilai & Pretest & & 81.08 \\
\hline
\end{tabular}

Berdasarkan tabel 1, terlihat bahwa keseluruhan responden adalah wanita dengan rata-rata usia 37.03 tahun, dengan usia termuda 29 tahun dan usia tertua 48 tahun. Sebagian besar adalah wali dari siswi SD Muhamadiyah Karang Tengah, dengan usia termuda 6 tahun dan usia tertua 11 
tahun. Nilai pretest rata-rata sebesar 62,39 , dan nilai posttest memiliki rata-rata lebih tinggi yakni 81.08. Adapun distribusi frekuensi pretest dan posttest disajikan pada tabel 2 dan tabel 3 sebagai berikut.

\begin{tabular}{rrr}
\multicolumn{3}{c}{ Tabel 2. Distribusi Frekuensi Pretest } \\
\hline Nilai & f & Persentase (\%) \\
\hline 30 & 1 & 2.2 \\
40 & 2 & 4.3 \\
50 & 8 & 17.4 \\
60 & 18 & 39.1 \\
70 & 9 & 19.6 \\
80 & 7 & 15.2 \\
90 & 1 & 2.2 \\
Total & 46 & 100 \\
\hline \multicolumn{3}{c}{} \\
\multicolumn{4}{c}{ Tabel 3. Distribusi Frekuensi Posttest } \\
\hline Nilai & F & \\
\hline 70 & 12 & Persentase $(\%)$ \\
80 & 21 & 26,1 \\
90 & 9 & 45,7 \\
100 & 4 & 19.6 \\
Total & 46 & 8.7 \\
& & 100 \\
\hline
\end{tabular}

Guna melihat kemaknaan statistik dari perbedaan nilai pretest-posttest, terlebih dahulu dilakukan uji normalitas pada skor pretest-posttest. Hal ini dilakukan untuk mengetahui normalitas sebaran data. Uji normalitas sampel $<50$ dilakukan dengan uji Shapiro Wilk dengan hasil (sig) $<0.05$, yang menunjukkan data tidak terdistribusi normal, sehingga nilai pretest dan posttest akan dianalisis menggunakan uji statistik non parametrik Wilcoxon Signed Rank Test. Uji homogenitas dilakukan dengan metode Levene's test dengan hasil sig $>0.05$ sehingga menunjukkan varian kedua kelompok homogen. Adapun hasil uji beda menggunakan uji Wilcoxon Signed Rank Test disajikan pada tabel 4.

\begin{tabular}{|c|c|c|}
\hline Keterangan & & Postest-pretest \\
\hline \multirow[t]{3}{*}{ Rank } & Negatif Rank & 2 \\
\hline & Positif Rank & 39 \\
\hline & Ties & 5 \\
\hline $\mathrm{Sig}$ & & 0.00 \\
\hline
\end{tabular}

Berdasarkan tabel 4, diketahui bahwa ne gatif rank (pretest>posttest) didapatkan pada 2 peserta, positif rank (posttest>pretet) didapatkan pada 39 peserta dan ties (pretest=posttest) didapatkan pada 5 peserta. Uji signifikansi perbedaan nilai pretest dan posttest didapatkan hasil sig $<0.05$, yang menunjukkan adanya perbedaan bermakna nilai sebelum dan sesudah pelaksanaan pelatihan, dengan nilai posttest lebih tinggi dari nilai pretest.

Melalui uji statistik diatas dapat terlihat bahwa pelatihan modul parenting pendampingan belajar anak di era digital dapat meningkatkan pengetahuan sebagian besar peserta pelatihan. Terdapat beberapa peserta dengan nilai pretest yang lebih tinggi dari posttest ataupun nilai pretest sama dengan nilai posttest, hal tersebut dapat disebabkan oleh berbagai faktor antara lain usia peserta, kualifikasi pendidikan maupun atensi peserta pada saat pemaparan yang sulit dikendalikan oleh pemateri karena pelaksanaan pengabdian dilakukan secara daring. Adanya peningkatakan pengetahuan orangtua diharapkan dapat meningkatkan kualitas dalam pendampingan belajar anak di era digital, meskipun aplikasi pengetahuan tersebut dan kendala yang dihadapi saat menerapkan pengetahuan memerlukan evaluasi lebih lanjut. Feedback positif didapatkan dari peserta setelah mengikuti pelatihan baik secara materi, penyampaian maupun kemanfaatan dan 
ketepatan materi pelatihan dengan kebutuhan mitra pengabdian.

\section{Simpulan}

Pengabdian masyarakat pelatihan modul parenting pendampingan belajar anak di era digital secara daring telah meningkatkan pengetahuan mitra pengabdian. Hal ini terlihat melalui evaluasi nilai sebelum dan sesudah pelaksanaan pelatihan.

\section{Ucapan Terima Kasih}

Tim pengabdian mengucapkan terimakasih kepada Universitas Muhammadiyah Yogyakarta melalui LP3M yang telah memberikan dana hibah pengabdian tahun 2019. Ucapan terima kasih juga diberikan kepada mitra pegabdian Paguyuban Orang Tua Siswa SD Muhammadiyah Karang Tengah dan Kepala Sekolah serta Guru SD Muhammadiyah Karang Tengah yang turut membantu perijinan dan pelaksanaan pengabdian.

\section{Daftar Pustaka}

Asosiasi Penyelenggara Jasa Internet Indonesia. (n.d.). Penetrasi Dan Perilaku Pengguna Internet Indonesia. Retrieved from https://web.kominfo.go.id/.../Laporan\%20Survei\%20APJII_2017.

Huntsinger, C., Jose, P. 2009. Parental involvement in children's schooling: Different meanings in different cultures. Early Childhood Research Quarterly (24) 398-410

Kildare, C., Middlemiss, S.2017. Impact of parents mobile device use on parent-child interaction: A literature review. Computers in Human Behavior 75 : 579-593. https://doi.org/10.1016/j.chb.2017.06.003

Paudel S, Jancey J, Subedi N, et al. Correlates of mobile screen media use among children aged 0-8: a systematic review. BMJ Open 2017;7:e014585. doi:10.1136/ bmjopen-2016014585

Saddock, S., 2010. Kaplan \& Sadock's Comprehensive Textbook Of Psychiatry, 9th ed. Lippincot

Steel, C.M.S. Web-based child pornography: The global impact of deterrence efforts and its consumption on mobile platforms. Child Abuse \& Neglect (2015), http://dx.doi.org/10.1016/j.chiabu.2014.12.009

Wonsun Shin (2018): Empowered parents: the role of self-efficacy in parental mediation of children's smartphone use in the United States, Journal of Children and Media, DOI: $10.1080 / 17482798.2018 .1486331$ 